\title{
Trophic impact of Atlantic bluefin tuna migrations in the North Sea
}

\author{
Mariani, Patrizio; Andersen, Ken Haste; Lindegren, Martin ; MacKenzie, Brian
}

Published in:

ICES Journal of Marine Science

Link to article, DOI:

10.1093/icesjms/fsx027

Publication date:

2017

Document Version

Peer reviewed version

Link back to DTU Orbit

Citation (APA):

Mariani, P., Andersen, K. H., Lindegren, M., \& MacKenzie, B. (2017). Trophic impact of Atlantic bluefin tuna migrations in the North Sea. ICES Journal of Marine Science, 74(6), 1552-1560.

https://doi.org/10.1093/icesjms/fsx027

\section{General rights}

Copyright and moral rights for the publications made accessible in the public portal are retained by the authors and/or other copyright owners and it is a condition of accessing publications that users recognise and abide by the legal requirements associated with these rights.

- Users may download and print one copy of any publication from the public portal for the purpose of private study or research.

- You may not further distribute the material or use it for any profit-making activity or commercial gain

- You may freely distribute the URL identifying the publication in the public portal

If you believe that this document breaches copyright please contact us providing details, and we will remove access to the work immediately and investigate your claim. 
1 Trophic impact of Atlantic bluefin tuna migrations in the North Sea

2

3 Patrizio Mariani ${ }^{1 *}$, Ken H Andersen ${ }^{1}$, Martin Lindegren ${ }^{1}$, Brian R MacKenzie ${ }^{1}$

4

${ }^{1}$ Centre for Ocean Life, National Institute for Aquatic Resources, Technical University of Denmark, Charlottenlund, Denmark

$8 *$ Corresponding author:

9 Patrizio Mariani

10 Kavalergården 6, 2920 Charlottenlund

11 Denmark

12 phone: +4535883353

13 fax: +4535883311

14 pat@aqua.dtu.dk

15 
Abstract

17 Large highly migratory predators can have major impacts on local marine ecosystems

18 by reducing prey populations and leading to trophic cascades that affect the entire fish community. These trophic interactions are typically non-linear and can alter both the migratory behavior of the predator and the stability of the fish community. The impact of a migrating top-predator is investigated here for Atlantic bluefin tuna in the North Sea. Bluefin tuna has been absent from the region for half-century, but recent years have seen recovery of migrations and a return of bluefin tuna in the area. We use a size spectrum model to analyse the trophic impact of the returning tuna on the entire fish community, under scenarios with varying levels of tuna consumption and fishing mortality on the prey. We show that with high level of prey fishing mortality in the North Sea, the effect of a tuna re-colonization results in only limited trophic cascades. However, high tuna consumption or changes in fishing mortality may result in a sudden recruitment failure of small-pelagic fish due to cascading effects on the fish community. In present-day conditions, the level of tuna consumption that triggers recruitment failure is lower at increasing fishing mortalities on their prey, providing indications for the future sustainable management of both small-pelagics and bluefin tuna in the area.

Keywords: fish community, long distance migration, size spectrum model, trophic cascade 


\section{Introduction}

Trophic relationships form the backbone of the functioning and biodiversity of ecosystems (Paine 1966, Worm and Duffy 2003). Several factors can affect the magnitude and importance of trophic interactions driving non-linear processes and complex dynamics in food webs (Levin 1998). For example, changes in the abundance of individuals in one trophic level can elicit direct and indirect changes on other trophic levels, a process known as a trophic cascade (Paine 1980, Pace et al., 1999, Polis et al., 2000). Evidences of trophic cascades have been reported both in terrestrial and in aquatic ecosystems (Pace et al., 1999, Shurin et al., 2002, Schmitz et al., 2004, Casini et al., 2008, Frank et al., 2005) supporting the hypothesis of a widespread process in ecosystem dynamics. Ecologists have often debated about how ubiquitous trophic cascades are in ecosystems (Polis 1994, Polis et al., 2000) partly because several compensatory mechanisms can dampen or eliminate the effects of trophic cascades (Pace et al., 1999, Cury et al., 2003, Andersen and Pedersen, 2010, Heath et al., 2014, Lindegren et al., 2016). It has been shown that in marine food webs a high degree of connectivity, presence of omnivory, ontogenic diet shifts and fishing can all prevent or dampen trophic cascades (Baum and Worm 2009, Andersen and Pedersen, 2010). Nonetheless, high fishing pressure has been suggested to trigger regime shifts in large marine ecosystems (Daskalov et al., 2007, Möllmann et al., 2009) and are likely responsible for recent changes in the fish community structure in coastal ecosystems (Jackson et al., 2001).

Generally, cascades are initiated by any external perturbation that can lower the abundance of some part of the community. Thus apart from fishing, another example of an external perturbation is the appearance of migrating larger predators that consume substantial amounts of prey over a relative narrow time period (Polis, 1994, Scheffer et al. 2005). Casini et al. (2012) showed that when high abundances of Baltic cod Gadus morhua migrated into unoccupied habitats in the Baltic Sea, their predatory impact induced four-level trophic cascades in the forage fish, zooplankton and phytoplankton communities of the region.

Atlantic bluefin tuna (Thunnus thynnus) is one of the largest apex predators in some north Atlantic marine ecosystems and have declined due mainly to overexploitation (Fromentin and Powers, 2005). This species used to migrate into the North Sea region for many years in the early-mid 1900s but ceased to do so in the mid-1960s and has been rare or absent during most years ever since (Mather et al., 1995; MacKenzie and Myers 2007; Fromentin and Restrepo 2008), but the last 2-3 years have provided evidence of their reappearance (Waage 2016, Bursell 2016; Thuesen Bleeg 2016; Christiansen and Gyldenkræne 2016). Bluefin tuna migrated mainly from the Mediterranean Sea spawning ground and remained in the North Sea region for 2-4 months before migrating southward in the autumn (Tiews 1978). While present in the North Sea, tuna consumption of prey (mainly mackerel and herring) has been estimated to be large ( $\sim 300$ kton per year) with a likely large impact on the distribution of the local fish community (Tiews 1978). This species has recently reappeared in the northern North Sea and Norwegian Sea. Norway has recently been allocated a commercial fishing quota from ICCAT increasing from about $36 \mathrm{Mt}$ to 52 Mt in the period 2015 - 2017 (ICCAT 2014a), and its entire quota for 2016 was captured in a single haul with 190 tunas (Waage 2016). The presence of tunas has been also reported in the inner North Sea with observations of both vagrant individuals and schools in the Skagerrak and Kattegat in 2015 and 2016 (Bursell 
2016; Thuesen Bleeg 2016; Christiansen and Gyldenkræne 2016). Additionally Atlantic bluefin tuna has recently appeared in other northern areas of the north Atlantic such as Denmark Strait and east Greenland (MacKenzie et al., 2014).

In this paper, our objective is to analyse the trophic effects induced by the reappearance of Atlantic bluefin tuna (henceforth tuna) on the northern North Sea food web. We investigate whether predation by tuna could have impacts on trophic levels farther down the food web through trophic cascades and evaluate the effects of interactions between tuna consumption and fishing mortality on the prey. We use a size- and trait-based model for the fish community that is able to account for the changes in trophic levels during ontogeny and resolve fishing mortality on larger sizes (Andersen and Pedersen 2010). The model is used to reconstruct the North Sea fish community size spectra under different scenarios of tuna migration and fishing pressure and allows estimating trophic cascades induced by predation from this top predator.

\section{Methods \\ Model formulation}

We use a previously published size-spectrum model to represent the baseline fish community (Andersen and Pedersen, 2010; see appendix for concise description including equations and parameters). The model is a trait-based size spectrum model (Andersen et al., 2016) based on a description of the energy budget of individuals. All rates and processes are parameterized using the size of individuals and the asymptotic size of species (Hartvig et al., 2011). The result of the model is the distribution of individual abundances $n\left(w, W_{\infty}, t\right)$ as function of size $w$, asymptotic size $W_{\infty}$ and variation over time, $t$. The central process in the model is predation of small individuals by large individuals. The food obtained from predation fuels growth and reproduction. Reproduction is limited by a Beverton-Holt stock-recruitment relationship to ensure coexistence of a continuum of asymptotic sizes, by introducing additional intra-specific density-dependence to population dynamics not represented by other processes in the model. Fishing mortality is imposed as a function of individual size and asymptotic size on all species (excluding tuna) and assuming a logistic size selectivity function, calibrated to emulate the fishing pattern in the North Sea (Pope et al., 2006). The total biomass of fish in the North Sea has been estimated to be between 8,600 kton and 13,000 kton (Sparholt 1990), which is consistent with estimates from multi-species fish stock assessment models providing 8,000 kton for the entire North Sea (ICES 2016). To simulate the northern North Sea fish community the total biomass of the ecosystem is set in the model as a fraction of what has been estimated and we use a reference biomass of 5,000 kton.

The impact of predation by tuna on the resident fish community is represented in the model as an extra predation mortality $\mu_{\mathrm{T}}$ inflicted on the size within the tunas' prey size preference $\phi_{T}\left(w_{p}\right)$ where $w_{p}$ is the weight of prey. Bluefin tuna are opportunistic predators and feed on a diverse diet, both in terms of species and sizes, and their diet composition more likely reflects available prey distributions and abundances in the surrounding environment than strong preferences for particular species or sizes (Goñi, and Arrizabalaga, 2010; Olafsdottir et al., 2016). We assume that the prey range of tuna is constrained within a minimum value $\left(w_{S}=100 \mathrm{gr}\right)$ and some large size $\left(w_{L}=2.5 \mathrm{~kg}\right)$, i.e., $w_{S} \leq w_{P} \leq w_{L}$. This size range approximates the size range of 
the dominant fish species known to be consumed by tuna in the North Sea during the 1950s-1960s (Tiews 1978) and by tunas in other northern shelf regions (e.g., Chase 2002, Overholtz 2005, Butler et al., 2010). However we also analyse the results at different values of $w_{S}$ to test the sensitivity of the model to this parameter.

The total consumption of tuna $S_{\mathrm{T}}$ can be calculated as (biomass per time):

$$
S_{\mathrm{T}}=\mu_{\mathrm{T}} \int w_{p} N\left(w_{p}\right) \phi_{T}\left(w_{p}\right) \mathrm{d} w_{p}
$$

where $N(w)$ is the community spectrum which is the integral over all asymptotic sizes: $N(w)=\int n\left(w, W_{\infty}\right) w \mathrm{~d} W_{\infty}$. Hence $w_{P} N\left(w_{P}\right)$ is equal to the total biomass in the prey range on which tuna can impose a predation mortality $\mu_{\mathrm{T}}$ with size preference $\phi_{T}\left(w_{p}\right)$. The equation for $S_{\mathrm{T}}$ can be rewritten to isolate the mortality:

$$
\mu_{\mathrm{T}}=S_{T} \frac{1}{\int w_{p} N\left(w_{p}\right) \phi_{T}\left(w_{p}\right) \mathrm{d} w_{p}} .
$$

which is then used as an extra mortality term in the integration of the model (Appendix 1).

We focus our analyses on four scenarios (Table 1): unperturbed ecosystems with no fishing or tuna consumption, i.e., fishing mortality $F=0$, consumption by tuna $S_{\mathrm{T}}=0$ $\left(N_{00}\right)$; an unexploited ecosystem with no fishing but with tuna consumption, i.e., $F=$ $0, S_{\mathrm{T}}=150$ kton year $^{-1}\left(N_{01}\right)$; an exploited ecosystem with high fishing but no tunas, $F=0.7$ year $^{-1}, S_{\mathrm{T}}=0\left(N_{10}\right)$; an exploited ecosystem with tunas, i.e., $F=0.7$ year $^{-1}, S_{\mathrm{T}}$ $=150 \mathrm{kton} /$ year $\left(N_{11}\right)$. In addition, we analyse the trophic impact of fishing and migrations for a larger range of fishing mortalities $\left(F \in[0-1.5]\right.$ year $\left.^{-1}\right)$ and tuna consumptions $\left(S_{T} \in[0-800] \mathrm{kton} /\right.$ year$)$.

Given a scenario with either fishing or tuna migration $\left(\left\{N_{10}, N_{01}, N_{11}\right\} \in \widetilde{N}\right)$, we can calculate the direct impact of tuna predation as the difference between $\widetilde{N}$ and the unperturbed case: $\int w_{p} \widetilde{N}-w_{P} N_{00} \mathrm{~d} w_{P}$. This difference in biomass estimates the direct trophic impact on the tuna prey range relative to an unperturbed scenario. Moreover, in order to estimate the trophic cascade initiated by tuna consumption we develop an index that expresses the total magnitude (regardless of sign) of the change in biomass relative to a reference size spectrum. The index $(\Delta)$ is defined as the integral of the size-spectra relative to the case of no tuna predation:

$$
\Delta=-\int_{w_{0}}^{w_{L}}\left|\log \frac{N_{\alpha 1}(w)}{N_{\alpha 0}(w)}\right| \mathrm{d}(\log w)
$$

where $N_{\alpha}$ indicates the specific fishing scenario considered (unexploited or exploited at different levels). This index is always positive and measures the change in size structure driven by tuna consumption for all sizes smaller than the maximum tuna's prey size $\left(w_{L}\right)$ but larger than the minimum size included in the model (i.e., fish egg size, $\left.w_{0}=0.5 \mathrm{mg}\right)$. We exclude from the computation effects on sizes larger than the maximum prey size $\left(w_{L}\right)$ as the abundance of those individuals is relatively low compared to smaller size classes, hence although perturbation can propagate upwards on the higher trophic levels and lead to a large change relative to the unexploited biomass, they have negligible effects on the absolute biomasses.

\section{Consumption by tuna in the northern North Sea}


Estimating the total prey consumption by tuna requires knowledge of their abundance, their body size, and their daily ration. No abundance estimates are available for this time period. However, by combining commercial catch data (ICCAT 2012) and estimates of instantaneous fishing mortality rates (Fromentin and Restrepo 2008) for the most important fishery in the region (i.e., the Norwegian fishery), it is possible to derive approximate estimates of biomass. Most of the Norwegian catches were made in ICES Subdivision IVa (Tiews 1978). We therefore assume that most of the foraging by this tuna biomass occurred in this region. Our tuna biomass and consumption estimates will therefore underestimate the total consumption because they exclude the catches by other countries; however non-Norwegian landings were relatively small (ca. $27 \%$ of all tuna landings in ICES Areas II-VII; Huse et al., 2015). We therefore provide sensitivity analyses of the model results to changes in $S_{\mathrm{T}}$.

We expressed the instantaneous fishing mortality rates on an annual basis, which allows estimation of the percentage of stock biomass removed annually. This removal rate can be considered as an annual exploitation rate, $U$ (Dick and MacCall 2011). Consequently, given the reported catches $(C)$ and the estimated $\mathrm{U}$, biomass in the region can be calculated (Worm et al., 2009; Rosenberg et al., 2014) as $B=C / U$, where $B$ is the total biomass. Note that $U$ is the fraction of the biomass removed by the fishery on an annual basis (i.e., obtained by converting the instantaneous fishing mortality rate to annual removal rates). The instantaneous fishing mortality rates were estimated to be $F=0.3, F=0.2$ and $F=0.1$ per year, for the years 1950 s, 1960 s and 1970s respectively (Fromentin and Restrepo 2008). These fishing mortality rates correspond approximately to annual removal rates of $26 \%, 18 \%$ and $10 \%$ respectively for the three time periods. As most of the individuals captured in this fishery were adults (Tiews 1978, Fromentin and Restrepo 2008), the biomass would correspond only to a spawning stock biomass (i.e., excluding juveniles) in this region. Indeed the reported weights in the catches (Tiews 1978) were mainly in the range $150-400 \mathrm{~kg}$. We used two reference tuna weights, $w_{1}=200 \mathrm{~kg}$ and $\mathrm{w}_{2}=300 \mathrm{~kg}$, to derive the total number of fish in the area $\left(\mathrm{n}_{1}=\mathrm{B} / \mathrm{w}_{1} ; \mathrm{n}_{2}=\mathrm{B} / \mathrm{w}_{2}\right)$ and the average daily consumptions of the population $\left(S_{\mathrm{T}}\right)$ using the allometric relationship (Innes et al., 1987, Overholtz 2005):

$$
S_{\mathrm{T}}=0.5 k\left(\mathrm{w}_{1}{ }^{0.8} \mathrm{n}_{1}+\mathrm{w}_{2}{ }^{0.8} \mathrm{n}_{2}\right)
$$

where $k=0.123$ and $S_{\mathrm{T}}$ has units of $\mathrm{kg}$ per day. Based on the relationship above we obtain an average daily individual consumption rate of $4 \%$ body weight. The daily ration of tuna in the North Sea and during the 1950s-60s has been previously assumed to be $3-6 \%$ day $^{-1}$ (Tiews 1978) and 1-4.7\% day ${ }^{-1}$ for tuna in the Gulf of MaineGeorges Bank during 1970-2002 (Overholtz 2005), which are then consistent with the estimates obtained above.

\section{Results}

Consumption by tuna in the northern North Sea

Norwegian landings of tuna in the region varied between 15 kton in 1952 to 0 kton after 1987. This corresponds to an estimated maximum biomass of about $B=60 \mathrm{kton}$ ( $B=14 \mathrm{kton}$, as average $1950-1987)$. We can then estimate the total annual consumption by tuna assuming a residence period of 100 days (Figure 1). This consumption is estimated to be between $100-200 \mathrm{kton} /$ year with a maximum value of $232 \mathrm{kton} /$ year in 1952. Moreover, as the catches declined, the tuna consumption 
decreases to around $30 \mathrm{kton} /$ year after 1963 and then to 0 in most recent periods. Those values compare well with previous estimates of tuna consumption in the area (Tiews 1978) (Figure 1).

\section{Community response to tuna migration and fishing}

241 At equilibrium and under unperturbed conditions $\left(N_{00} ; F=0, S_{\mathrm{T}}=0\right)$ the simulated (slope of -1.47), which provides the assumed total biomass of about 5,000 kton (Figure 2).

Assuming migration of tuna in this unperturbed system (Figure 3a), we find that the tuna consumption can substantially reduce the abundance of the larger prey in the feeding range $(w>1 \mathrm{~kg})$ and have positive indirect impacts on the smaller prey size classes $(0.1 \mathrm{~kg}<w<0.3 \mathrm{~kg})$. This is mainly because smaller sizes outside the tuna prey range experience a reduction of both predation pressure and competition from the larger sizes, thus contributing to more fish growing into the smallest tuna prey range. The perturbation generated by tuna consumption in the preferred prey range cascades down to smaller size ranges with gradually weaker effects (oscillations). The perturbation is indeed damped while moving from larger to smaller individuals and it becomes very small in the region dominated by zooplankton biomass $(w<0.5 \mathrm{~g})$.

The structure of this type of ecosystem is qualitatively different from the fish community simulated when fishing pressure is introduced $\left(N_{10}\right)$. In case of a fishing mortality $F=0.7$ year $^{-1}$ and no tuna consumption $\left(S_{\mathrm{T}}=0\right)$ the model results in a $20 \%$ increase in fish biomass within the range $0.1 \mathrm{~kg}<w<1 \mathrm{~kg}$. As above the increase in biomass in a certain range of sizes has cascading effects in the community size spectra. Hence, while negligible effects are predicted on the smaller size classes in the model, $w<10^{-2} \mathrm{~g}$, biomass increase and decreases are alternated throughout the fish community. Small perturbations to this general trophic cascade are introduced when tuna consumption is considered in this exploited scenario $\left(N_{11}\right.$, Figure $\left.3 \mathrm{a}\right)$. The main effect is the slight shifts of the peaks of the perturbation towards smaller sizes as a larger reduction of biomass occur in the larger tuna prey range. At equilibrium the highest biomass in the range $0.1 \mathrm{~kg}<w<2.5 \mathrm{~kg}$ is obtained in the exploited case with no tuna $\left(N_{10}\right)$ while the opposite conditions (no fishing, but tuna present, $N_{01}$ ) provides the lowest (Table 1). Trophic impact is then largest when tuna is introduced in an exploited scenario, while it becomes much smaller when the ecosystem is exposed to fishery (index $\Delta$ in Table 1 ).

The sensitivity of the fish community to tuna consumption in exploited or unexploited ecosystems is smaller when a larger prey size range is considered in the model (Figure $3 \mathrm{~b}$ ). Assuming tuna able to feed on prey as small as $w_{s}=1 \mathrm{~g}$ the relative change for both ecosystems is always very close to 1 with a trophic impact $\Delta \approx 0.1$ in both cases (Figure $3 \mathrm{c}$ ). In general an increase in the prey size range has damping effects on trophic cascades. Reducing the prey size range, by increasing $w_{s}$, larger effects of tuna consumption are simulated in the community structure and those are generally much stronger for unexploited ecosystems $(\Delta \approx 0.4$, Figure $3 \mathrm{c})$. Indeed the similarities between exploited and unexploited ecosystems rapidly disappear as the smallest prey item is increased to values larger than $20 \mathrm{~g}$. 
In case of no fishing the introduction of tuna in the ecosystem generates a lower equilibrium biomass in the prey range (Figure 4a). The higher the tuna consumption, the larger the reduction in prey biomass. A sharp transition towards low values of biomass (around $500 \mathrm{kton}$ ) is shown by the model at $S_{T} \approx 400 \mathrm{kton} / \mathrm{year}$ and no fishing $(\mathrm{F}=0)$. At this level of consumption, the prey biomass reaches a critical minimum spawning stock size that cannot support recruitment. With a low recruitment of the larger species in the prey range, the smaller prey can increase their biomass because of reduced predation. Hence, at this critical level, the temporal dynamic of the size spectrum model shows an oscillatory behaviour of the abundance of tunas' prey. The coefficient of variation (CV, i.e., standard deviation relative to the mean) in the abundance of prey fish within the tuna size range calculated over the last realizations of the model (i.e., last year) is generally small $(\mathrm{CV}<0.05)$, while it suddenly increases when the model approaches the critical transition $(C V \approx 0.6)$. However, those oscillations start occurring when the fish biomass is low, hence further increases in tuna consumption do not affect the outcome.

Introducing fishing will generally have positive effects on biomass in the range of the tuna prey. This occurs because the reduction of large fish (such as cod) reduces the predation pressure on small fish, which then increase in abundance. Indeed, at a moderate level of fishing $\left(0.5 \leq F \leq 1\right.$ year $\left.^{-1}\right)$ and no tuna migration, there is a maximum increase of 500 kton of tuna prey biomass produced (Figure 4a). Further increases in fishing mortality can however reduce smaller fish including the tuna prey size. The same conclusions can be drawn when both tuna migration and fishing are present in the model, resulting in a general non-linear relation between the two processes (Figure 4). Interestingly, at relatively low levels of fishing mortality $(F=$ 0.5 year $^{-1}$ ) up to $500 \mathrm{kton} / \mathrm{year}$ of tuna consumption can be present in the model without largely altering the prey biomass compared to an unperturbed scenario.

The direct impact of tuna on the entire fish community size structure can be evaluated at different values of consumption using the perturbation index $\Delta$ (Figure $4 \mathrm{~b}$ ). Since $\Delta$ is a measure relative to the absence of tuna migration (Eq. 3), the index start from $\Delta=0$ at all levels of fishing mortality and can be generally described as the area below a perturbation curve (Figure 3). Tuna can significantly affect the size structure of the community, $\Delta>0.5$, at high level of consumption or at low level of fishing mortality (Figure $4 \mathrm{~b}$ ). If $F$ is high the effect of tuna consumption on the size-structure is negligible. While at lower levels of fishing $(F \leq 0.6)$ the larger the tuna consumption, the greater is the effect on the food web. This pattern is evident up to the critical transition described above, where the collapse of the tuna prey range will largely impact the size-structure and any further increase in $S_{T}$ will not have any effects.

\section{Discussion}

Although it is recognized that predation in marine ecosystems is an important factor explaining food webs dynamics and community structure (Verity and Smetacek 1996, Heithaus et al., 2008, Baum and Worm 2009, Mariani et al., 2013), effects of top predators on the marine food web are more complex because of their cascading impact on the entire community (Cury et al., 2003, Ferretti et al., 2012, Blenckner et al., 2015). Our results show how effects of fishing and consumption of top predators can produce large changes in the small pelagic fish communities with cascading effects that are stronger at lower fishing mortalities. In the northern North Sea, with 
high level of fishing mortality, the biomass of small pelagic fish is only marginally controlled by predation of large top predators (e.g., cod, tunas, etc.). On the other hand at lower fishing mortality, consumption by top predators can significantly reduce the biomass of the small pelagic having cascading effects on other components

Thus, with an intermediate exploitation rate $\left(F \approx 0.3\right.$ year $\left.^{-1}\right)$, fishing may have beneficial effects for increasing small pelagic fish biomass, which can then potentially sustain consumption by migratory species such as tunas. Above these intermediate values $\left(F>0.5\right.$ year $\left.^{-1}\right)$, small pelagic fish biomass will also be reduced. Moreover, the model shows a critical threshold for tuna consumption above which both trophic impact on the fish community and small pelagic biomass are independent from predation (Figure 4). This can be explained by a strong decline of fish biomass in the preferred prey size range of tuna and the consequent failure in their recruitment. Assuming that the feeding ground in the northern North Sea has a total fish biomass of 5,000 kton and that tuna consumption could be in the range $100-200 \mathrm{kton} /$ year, then $2-4 \%$ of the entire fish community could be consumed by tunas in about 100 days. However, the consumption is concentrated in the preferred size range $\left(w_{S} \leq w_{P} \leq w_{L}\right)$ and at certain levels can become critical for the recruitment of species in this range. Presently this critical level is at high values of tuna consumption for the prey size range $0.1 \leq w_{P} \leq 1.5 \mathrm{~kg}$. Indeed, when consumption by migrating predators is at $650 \mathrm{kton}(13 \%$ of the entire fish community) and $F=0.7$ per year, the recruitment of some prey species (Eq. M10 in the Appendix) oscillates around values of $R_{0} \approx 1$, hence the biomass of fish within the tuna preferred size range remains at a minimum level with large impact on the trophic cascade.

Overall tuna biomass in the northeast Atlantic and Mediterranean Sea has been increasing during the past 5-10 years (ICCAT 2014b) which should also stimulate tuna to explore new (or former) foraging areas. There is ample evidence that migratory species can explore the environment and discover new areas for feeding (Dingle and Drake 2007, Alerstam et al., 2003, Aidley 1981, Hays et al., 2014). Recently, migrations of mackerel and bluefin tuna have been observed in waters east of Greenland (Denmark Strait), an area that was not previously occupied by either species (MacKenzie et al., 2014; Jansen et al., 2016). Those changes are likely driven by improved conditions of the habitats in northern areas (e.g., increase in temperature and food) and can now have cascading effects on the local fish community. Indeed, a re-appearance of tuna in the northern North Sea would presently have negligible effects on both size-structure and pelagic biomass, since the fishing pressure in the area is much greater than the potential impact of tuna feeding. Despite the presently negligible food web effects of tuna consumption in the northern North Sea a future increase in tuna biomass could lead to pronounced changes in both size-structure and pelagic biomass acting across larger spatial scales. Although a higher tuna biomass would inevitably lead to calls for tuna fishing quotas by several Countries surrounding the North Sea, the historical lesson learned from the past stock collapse and disappearance of tuna would arguably motivate exploitation levels to be kept at a low and sustainable level. Whether these levels would promote a tuna biomass at a level at which consumption critically affects the prey population and the ecosystem as a whole remains to be seen. However any fishing-related removal of tunas would reduce the trophic impacts by reducing the tuna consumption within a range consistent with that considered in the present study. 
In addition, it may be suggested that not only tuna but also other large fish predators with similar size and partially overlapping diet preferences could invade or recolonize the North Sea under future climate change. One such competing species could be the warm-water predator swordfish (Xiphias gladius) (Stillwell and Kohler 1985), which at least during the Stone Age used to inhabit these waters and could potentially recolonize given future increases in temperature (Enghoff et al. 2007). Recent occurrences in Norwegian waters suggest that such a scenario is indeed very likely (Sundby et al., 2013) . Given that our model approach is not species-specific but generalizable to all fish across a great range of sizes, a potential increase in such ecologically similar predators would simply serve to increase the consumption of prey fish within the size range of tuna and support our findings on potential future changes in the North Sea food with respect to its fish prey biomass and size structure.

Evidences of rapid trophic cascades driven by seasonal migration of top predators have been suggested in the Baltic Sea where periodic migrations of cod and its consumption on herring led to cascading effects across multiple trophic levels in the Gulf of Riga (Casini et al., 2012). We note that fishing mortality on herring in the area is about $F=0.4 \mathrm{yr}^{-1}$ (ICES 2014) which in our model would allow a significant trophic impact also at low values of predator consumption (Fig 4b). Moreover, the patterns in trophic cascades observed in the Gulf of Riga are consistent with our tuna results because they show larger impact on the prey (herring) and weaker impact on the other components of the ecosystem (plankton) (Fig 3).

Recent estimates of the total amount of fish in the entire North Sea are ca. 8,000 kton, (ICES 2016) thus our assumption of 5,000 kton could be reasonable for the northern North Sea. However, changes in prey size range or total fish biomass can affect our results. A change in the total fish biomass in the model is equivalent to a change in the consumption levels of tunas, hence similar effects are produced both in terms of biomass available to tuna feeding or in terms of trophic impact (Figure 4). Indeed, if the fish community is assumed to have a lower total biomass, the critical transition point is shifted towards smaller consumption levels. Beyond this threshold the decrease in prey biomass becomes insensitive to further increases in tuna consumption or, similarly, to reduction in total fish biomass. A wider prey size range for tuna can significantly reduce the trophic impact of consumption. This is because the amount of biomass available to tuna is larger and the feeding impact evenly distributed over a wider size-spectra. On the contrary, a narrower prey size range can induce stronger trophic-cascades illustrated by larger values of the perturbation index $\Delta$.

Our findings illustrate interactions between migration behaviour and trophic impacts of a migratory predator on a food web. As such, they provide an additional ecosystem context for the management of both forage species in the North Sea and for tuna itself. This knowledge could be useful for understanding the conditions that could allow tuna to re-establish a migration path that was lost in the $1960 \mathrm{~s}$, as well as the food web consequences of such a feeding migration. The sudden interruption of fish migration towards certain feeding areas has been explained by a loss of group collective memory driven by the breaking of the social transmission of the information (Petitgas et al., 2010; De Luca et al., 2014). Removing those individuals that had some information and preference for specific feeding areas has likely produced a rapid change in the migratory behaviour of the rest of the group that has likely moved towards other areas (De Luca et al., 2014). Hence, given that food 
resources are now available for tuna, the recent re-appearance in the region might represent the beginnings of a re-establishment of the migratory path towards the northern North Sea. This re-establishment will proceed if some of the individuals that were able to rediscover this historical feeding area will survive to restore this

441 information in the tuna population.

442

\section{Acknowledgements}

446 Part of the research leading to these results has received support from the EU-FP7 project EURO-BASIN (grant agreement no. 264933).

448 


\section{References}

Aidley, D. J. (Ed.). 1981. Animal migration (Vol. 13). CUP Archive.

Alerstam, T., Hedenström, A., \& Åkesson, S. 2003. Long-distance migration: evolution and determinants. Oikos, 103(2), 247-260.

Andersen, K. H., Jacobsen, N. S. and Farnsworth, K.D. 2016. The theoretical foundations for size spectrum models of fish communities. Canadian Journal of Fisheries and Aquatic Science. 73(4): 575588. doi:10.1139/cjfas-2015-0230

Andersen, K. H., and Pedersen, M. 2010. Damped trophic cascades driven by fishing in model marine ecosystems. Proceedings of the Royal Society B: Biological Sciences, 277(1682), 795-802.

Baum, J. K., \& Worm, B. 2009. Cascading top down effects of changing oceanic predator abundances. Journal of Animal Ecology, 78(4), 699-714.

Blenckner T, Llope M, Möllmann C, Voss R, Quaas MF, Casini M, Lindegren M, Folke C, Chr. Stenseth N. 2015. Climate and fishing steer ecosystem regeneration to uncertain economic futures. Proceedings of the Royal Society B: Biological Sciences, 282: 20142809. http://dx.doi.org/10.1098/rspb.2014.2809

Britten, G.L., Dowd, M., Minto, C., Ferretti, F., Boero, F. and Lotze, H.K. 2014. Predator decline leads to decreased stability in a coastal fish community. Ecology letters, 17(12), pp.1518-1525.

Bursel, J. 2016. 400 kilo + tun genudsat I dansk forvand! In Fisk og Fri, September 2016, http://www.fiskogfri.dk/400-kilo-tun-genudsat-i-dansk-farvand/ (Accessed: 29 ${ }^{\text {th }}$ January 2017).

Butler, C. M., Rudershausen, P. J., and Buckel, J. A. 2010. Feeding Ecology of Atlantic Bluefin Tuna (Thunnus Thynnus) in North Carolina: Diet, Daily Ration, and Consumptionof Atlantic Menhaden (Brevoortia Tyrannus). Fish. Bull. 108, 56-69.

Casini, M., Lövgren, J., Hjelm, J., Cardinale, M., Molinero, J. C., \& Kornilovs, G. 2008. Multi-level trophic cascades in a heavily exploited open marine ecosystem. Proceedings of the Royal Society B: Biological Sciences,275(1644), 1793-1801.

Casini, M., Blenckner, T., Möllmann, C., Gårdmark, A., Lindegren, M., Llope, M., Kornilovs, G., Plikshs, M. and Stenseth, N.C. 2012. Predator transitory spillover induces trophic cascades in ecological sinks. Proceedings of the National Academy of Sciences, 109(21), pp.8185-8189.

Chase, B. C. 2002. Differences in diet of Atlantic bluefin tuna (Thunnus thynnus) at five seasonal feeding grounds on the New England continental shelf. Fish. Bull.-Natl. Ocean. ATMOSPHERIC Adm. $100,168-180$.

Chen, H., Hagerty, S., Crotty, S.M. and Bertness, M.D. 2016. Direct and indirect trophic effects of predator depletion on basal trophic levels. Ecology, 97(2), pp.338-346.

Christiansen, M. \& Gyldenkræne, P. Nordjysk lystfisker jubler: der er blåfinnede tun overalt. Danmarks Radio Nyheder (2016), https://www.dr.dk/nyheder/indland/nordjysk-lystfisker-jubler-der-erblaafinnede-tun-overalt (Accessed: $29^{\text {th }}$ January 2017).

Cury, P., Shannon, L., \& Shin, Y. J. 2003. The functioning of marine ecosystems: a fisheries perspective. Responsible fisheries in the marine ecosystem, 103-123.

De Luca, G., Mariani, P., MacKenzie, B. R., \& Marsili, M. 2014. Fishing out collective memory of migratory schools. Journal of The Royal Society Interface, 11(95), 20140043.

de Roos, A.M., Persson, L. 2001. Physiologically structured models - from versatile technique to ecological theory. Oikos 94, 51-71. 
Daskalov, G.M., Grishin, A.N., Rodionov, S. and Mihneva, V., 2007. Trophic cascades triggered by overfishing reveal possible mechanisms of ecosystem regime shifts. Proceedings of the National Academy of Sciences, 104(25), pp.10518-10523.

De Luca, G., Mariani, P., MacKenzie, B.R. and Marsili, M., 2014. Fishing out collective memory of migratory schools. Journal of The Royal Society Interface, 11, p.20140043.

DOI:10.1098/rsif.2014.0043

Dick, E. J., and MacCall, A. D. 2011. Depletion-Based Stock Reduction Analysis: A catch-based method for determining sustainable yields for data-poor fish stocks. Fisheries Research, 110: 331-341. http://www.sciencedirect.com/science/article/pii/S0165783611001962 (Accessed 16 August 2016).

Dingle, H., \& Drake, V. A. 2007. What is migration? Bioscience, 57(2), 113-121.

Doughty, C.E., Roman, J., Faurby, S., Wolf, A., Haque, A., Bakker, E.S., Malhi, Y., Dunning, J.B. and Svenning, J.C. 2015. Global nutrient transport in a world of giants. Proceedings of the National Academy of Sciences, p.201502549.

Enghoff, I.B., MacKenzie, B.R. and Nielsen, E.E., 2007. The Danish fish fauna during the warm Atlantic period (ca. 7000-3900bc): Forerunner of future changes? Fisheries Research, 87(2), pp.167180.

Ferretti, F., Osio, G. C., Jenkins, C. J., Rosenberg, A. A., \& Lotze, H. K. 2013. Long-term change in a meso-predator community in response to prolonged and heterogeneous human impact. Scientific reports, 3 .

Fiskeritidende 2016. Større bestand af tun på vej. p. 5 (in Danish), n. 23, $9^{\text {th }}$ July 2016

Frank, K. T., Petrie, B., Choi, J. S., \& Leggett, W. C. 2005. Trophic cascades in a formerly coddominated ecosystem. Science, 308(5728), 1621-1623.

Fromentin, J.M. and Powers, J.E. 2005. Atlantic bluefin tuna: population dynamics, ecology, fisheries and management. Fish and Fisheries, 6(4), pp.281-306.

Fromentin, J. M., \& Restrepo, V. 2008. A year-class curve analysis to estimate mortality of Atlantic bluefin tuna caught by the Norwegian fishery from 1956 to 1979. Collective Volume of Scientific Papers, 64(2), 480-490.

Fromentin, J.M., Reygondeau, G., Bonhommeau, S. and Beaugrand, G. 2014. Oceanographic changes and exploitation drive the spatio-temporal dynamics of Atlantic bluefin tuna (Thunnus thynnus). Fisheries Oceanography, 23(2), pp.147-156.

Goñi, N. and Arrizabalaga, H. 2010. Seasonal and interannual variability of fat content of juvenile albacore (Thunnus alalunga) and bluefin (Thunnus thynnus) tunas during their feeding migration to the Bay of Biscay. Progress in Oceanography, 86(1), pp.115-123.

Hartvig, M., Andersen, K. H., \& Beyer, J. E. 2011. Food web framework for size-structured populations. Journal of Theoretical Biology, 272(1), 113-122.

Hays, G. C., Christensen, A., Fossette, S., Schofield, G., Talbot, J., \& Mariani, P. 2014. Route optimisation and solving Zermelo's navigation problem during long distance migration in cross flows. Ecology letters, 17(2), 137-143.

Heath, M.1 R., D. C. Speirs, and J. H. Steele 2014. "Understanding patterns and processes in models of trophic cascades." Ecology letters 17.1: 101-114.

Heithaus, M. R., Frid, A., Wirsing, A. J., \& Worm, B. 2008. Predicting ecological consequences of marine top predator declines. Trends in Ecology \& Evolution, 23(4), 202-210. 
Huse, G., MacKenzie, B.R., Trenkel, V., Doray, M., Nøttestad, L. and Oskarsson, G. 2015. Spatially explicit estimates of stock sizes, structure and biomass of herring and blue whiting, and catch data of bluefin tuna. Earth System Science Data, 7(1), pp.35-46.

ICCAT 2012. Report of the 2012 Atlantic Bluefin Tuna Stock Assessment Session. Doc. No. SCI-033 / 2012, p. 124.

ICCAT 2014a. Recommendation by ICCAT amending the recommendation 13-07 by ICCAT to establish a multi-annual recovery plan for bluefin tuna in the eastern Atlantic and Mediterranean. Reccomendation 14-04, pp. 35.

ICCAT 2014b. Report of the 2014 Atlantic Bluefin Tuna Stock Assessment Session (Madrid, Spain September 22 to 27, 2014). SCRS Plenary Sessions 9 to 21. Pages 1-178.

ICES 2014. Report of the Baltic Fisheries Assessment Working Group (WGBFAS), 3-10 April 2014. ICES Headquarters, Copenhagen ICES CM 2014/ACOM:10

ICES 2016. Report of the Working Group on Multispecies Assessment Methods (WGSAM), 9-13 November 2015, Woods Hole, USA. ICES CM 2015/SSGEPI:20. 206 pp.

Innes, S., Lavigne, D. M., Earle, W. M., \& Kovacs, K. M. 1987. Feeding rates of seals and whales. The Journal of Animal Ecology, 115-130.

Jackson, J.B., Kirby, M.X., Berger, W.H., Bjorndal, K.A., Botsford, L.W., Bourque, B.J., Bradbury, R.H., Cooke, R., Erlandson, J., Estes, J.A. and Hughes, T.P., 2001. Historical overfishing and the recent collapse of coastal ecosystems. science, 293(5530), pp.629-637.

Jansen, T..Post, S. Kristiansen, T., Óskarsson, G. J., Boje, J., MacKenzie, B. R., Broberg, M. and Siegstad, H. 2016. Ocean warming expands habitat of a rich natural resource and benefits a national economy. Ecological Applications 26: 2021-2032. DOI: 10.1002/eap.1384

Jennings, S., Greenstreet, S., \& Reynolds, J. 1999. Structural change in an exploited fish community: a consequence of differential fishing effects on species with contrasting life histories. Journal of Animal Ecology, 68(3), 617-627.

Jennings, S. and Blanchard, J.L. 2004. Fish abundance with no fishing: predictions based on macroecological theory. Journal of Animal Ecology, 73(4), pp.632-642.

Levin, S. A. 1998. Ecosystems and the biosphere as complex adaptive systems. Ecosystems, 1(5), 431436.

Lindegren, M., Checkley, D.M., Jr., Ohman, M.D., Koslow, A., Goericke, R. 2016. Resilience and Stability of a Pelagic Marine Ecosystem. Proceedings of the Royal Society B-Biological Sciences, 283: 20151931

Lotze, H.K. and McClenachan, L. 2014. Marine historical ecology: informing the future by learning from the past. Marine Community Ecology and Conservation, pp.165-200.

MacKenzie, B. R., Payne, M., Boje, J., Højer, J. L., Siegstad, H. 2014. A cascade of warming impacts brings bluefin tuna to Greenland waters. Global Change Biology 20: 2484-2491, doi: $10.1111 /$ gcb. 12597

MacKenzie, B.R. and Myers, R.A., 2007. The development of the northern European fishery for north Atlantic bluefin tuna Thunnus thynnus during 1900-1950. Fisheries Research, 87(2), pp.229-239.

Mariani, P., \& Visser, A. W. 2010. Optimization and emergence in marine ecosystem models. Progress in Oceanography, 84(1), 89-92. 

Mather, F.J., Mason, J.M. and Jones, A.C., 1995. Historical document: life history and fisheries of Atlantic bluefin tuna. NOAA Technical Memorandum NMFS-SEFSC 370: 1-165.

McCauley, D.J., Pinsky, M.L., Palumbi, S.R., Estes, J.A., Joyce, F.H. and Warner, R.R. 2015. Marine defaunation: Animal loss in the global ocean. Science, 347(6219), p.1255641.

Myers, R. A., Baum, J. K., Shepherd, T. D., Powers, S. P., \& Peterson, C. H. 2007. Cascading effects of the loss of apex predatory sharks from a coastal ocean. Science, 315(5820), 1846-1850.

Möllmann, C., Diekmann, R., Müller-Karulis, B., Kornilovs, G., Plikshs, M. and Axe, P., 2009. Reorganization of a large marine ecosystem due to atmospheric and anthropogenic pressure: a discontinuous regime shift in the Central Baltic Sea. Global Change Biology, 15(6), pp.1377-1393.

Olafsdottir, D., MacKenzie, B. R., Chosson-P, V., Ingimundardottir, T. 2016. Dietary evidence of mesopelagic and pelagic foraging by Atlantic bluefin tuna (Thunnus thynnus L.) during autumn migrations to the Iceland Basin. Frontiers in Marine Science 3: Article 106, June 2016; 23 pp. http://dx.doi.org/10.3389/fmars.2016.00108.

Overholtz, W. J. 2006. Estimates of consumption of Atlantic herring (Clupea harengus) by bluefin tuna (Thunnus thynnus) during 1970-2002: an approach incorporating uncertainty. J. Northwest Atl. Fish. Sci, 36, 55-63.

Pace, M. L., Cole, J. J., Carpenter, S. R., \& Kitchell, J. F. 1999. Trophic cascades revealed in diverse ecosystems. Trends in ecology \& evolution,14(12), 483-488.

Paine, R. T. 1966. Food web complexity and species diversity. American Naturalist, 65-75.

Paine, R. T. 1980. Food webs: linkage, interaction strength and community infrastructure. Journal of Animal Ecology, 49(3), 667-685.

Petitgas, P., Secor, D.H., McQuinn, I., Huse, G. and Lo, N. 2010. Stock collapses and their recovery: mechanisms that establish and maintain life-cycle closure in space and time. ICES Journal of Marine Science: Journal du Conseil, 67(9), pp.1841-1848.

Pinnegar, J. K., Polunin, N. V. C., Francour, P., Badalamenti, F., Chemello, R., Harmelin-Vivien, M. L., Hereu, B., Milazzo, M., Zabala, M., D’Anna, G., \& Pipitone, C. 2000. Trophic cascades in benthic marine ecosystems: lessons for fisheries and protected-area management. Environmental Conservation, 27(02), 179-200.

Polis, G. A. 1994. Food webs, trophic cascades and community structure. Australian Journal of Ecology, 19(2), 121-136.

Polis, G. A., Holt, R. D., Menge, B. A., \& Winemiller, K. O. 1996. Time, space, and life history: influences on food webs. In Food Webs (pp. 435-460). Springer US.

Polis, G. A., Sears, A. L., Huxel, G. R., Strong, D. R., \& Maron, J. 2000. When is a trophic cascade a trophic cascade?. Trends in Ecology \& Evolution, 15(11), 473-475.

Pope, J. G., Rice, J. C., Daan, N., Jennings, S. \& Gislason, H. 2006 Modelling an exploited marine fish community with 15 parameters — results from a simple size-based model. ICES J. Mar. Sci. 63, 10291044 .

Rosenberg, A. A., Fogarty, M. J., Cooper, A. B., Dickey-Collas, M., Fulton, E. A., Gutierrez, N. L., Hyde, K. J. W., et al. 2014. Developing new approaches to global stock status assessment and fishery production potential of the seas. FAO Fisheries and Aquaculture Circular (Rome), 1086: 1-175.

Scheffer, M., Carpenter, S., \& Young, B. D. 2005. Cascading effects of overfishing marine systems. Trends in Ecology \& Evolution, 20(11), 579-581. 
Schmitz, O. J., Krivan, V., \& Ovadia, O. 2004. Trophic cascades: the primacy of trait mediated and Halpern, B.S. 2002. A cross ecosystem comparison of the strength of trophic cascades. Ecology letters, 5(6), pp.785-791.

Sparholt, H., 1990. An estimate of the total biomass of fish in the North Sea. Journal du Conseil: ICES Journal of Marine Science, 46(2), pp.200-210.

Steneck, R., \& Sala, E. 2005. Large marine carnivores: trophic cascades and top-down controls in coastal ecosystems past and present (pp. 110-37). University of Maine Sea Grant College Program.

Stillwell, C.E. and Kohler, N.E., 1985. Food and feeding ecology of the swordfish Xiphias gladius in the western North Atlantic Ocean with estimates of daily ration. Marine ecology progress series, 22(3), pp.239-247.

Sundby, S., Nøttestad, L., Myklevoll, S. and Tangen, Ø., 2013. Swordfish towards the Arctic Atlantic in climate change. COLLECT. VOL. SCI. PAP. ICCAT, 69(3), pp.1296-1303.

Tiews, K. 1978. On the disappearance of bluefin tuna in the North Sea and its ecological implications for herring and mackerel. Rapports et Proces-Verbaux des Reunions Int. Explor. Mer., 172: 301-309.

Thuesen Bleeg, M. 2016. Her får danske fiskere den forbudte gigantfangst på 450 kilo krogen: - Ikke for små drenge, http://livsstil.tv2.dk/2016-09-24-her-faar-danske-fiskere-den-forbudte-gigantfangstpaa-450-kilo-krogen-ikke-for-smaa (Accessed $29^{\text {th }}$ January 2017).

Verity, P. G., \& Smetacek, V. 1996. Organism life cycles, predation, and the structure of marine pelagic ecosystems. Marine ecology progress series. Oldendorf, 130(1), 277-293.

Werner, E. E., \& Peacor, S. D. 2003. A review of trait-mediated indirect interactions in ecological communities. Ecology, 84(5), 1083-1100.

Waage, N. 2016. Fishermen and oceanographers rejoice over major bluefin tuna catch. In Norway Today, September 2016, http://norwaytoday.info/finance/cheers-large-catches-bluefin-tuna/ (Accessed: $29^{\text {th }}$ January 2017).

Worm, B., \& Duffy, J. E. 2003. Biodiversity, productivity and stability in real food webs. Trends in Ecology \& Evolution, 18(12), 628-632.

Worm, B., Hilborn, R., Baum, J. K., Branch, T. A., Collie, J. S., Costello, C., Fogarty, M. J., et al. 2009. Rebuilding global fisheries. Science, 325: 578-585.

Worm, B., \& Tittensor, D. P. 2011. Range contraction in large pelagic predators. Proceedings of the National Academy of Sciences, 108(29), 11942-11947. 
Tables and Figures 735 Table 1. Description of case studies with indication of fishing mortality $(F)$ and tuna consumption $\left(\mathrm{S}_{\mathrm{T}}\right)$.
736 Fishing mortality does not include tuna population. Also shown calculated values of fish biomass in the tuna's preferred size range and the trophic impact index $(\Delta)$.

\begin{tabular}{|c|c|c|c|c|}
\hline Case & $\begin{array}{c}\boldsymbol{F} \\
\text { year }^{-1}\end{array}$ & $\begin{array}{c}\mathbf{S}_{\mathbf{T}} \\
\text { kton year }^{-1}\end{array}$ & $\begin{array}{c}\text { Prey biomass } \\
\text { kton year }^{-1}\end{array}$ & $\Delta$ \\
\hline$N_{00}$ & 0 & 0 & 775 & - \\
\hline$N_{01}$ & 0 & 150 & 633 & 0.33 \\
\hline$N_{10}$ & 0.7 & 0 & 1286 & - \\
\hline$N_{11}$ & 0.7 & 150 & 1181 & 0.14 \\
\hline
\end{tabular}




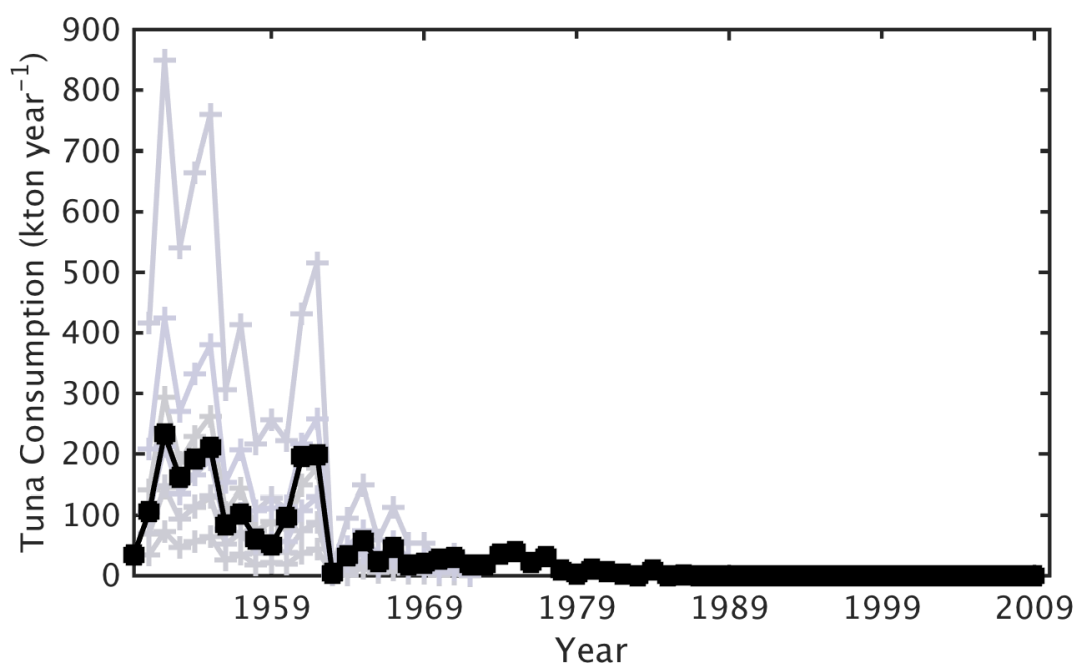

Figure 1. Total prey biomass consumed per year by tuna migrating into the northern North Sea between 1950 and 2009. Our values (black line) are compared with a series of estimates from Tiews (1978) (cfr. Table 150, grey lines). Catch data of the Norwegian fleet have been transformed to total biomass and then into daily consumption. The total consumed biomass is calculated assuming 100 days of feeding in the area and is used to define the parameter $S_{\mathrm{T}}$. 


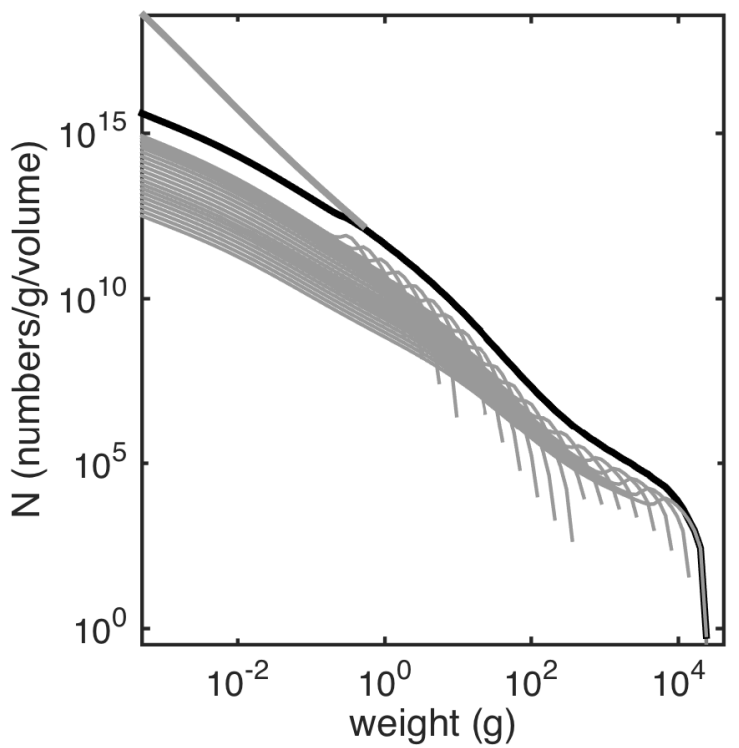

Figure 2. Abundance size spectra of 25 asymptotic size classes in an unperturbed ecosystem (thin grey lines) and community spectrum (black line) and the zooplankton resource spectrum (thick grey line). 

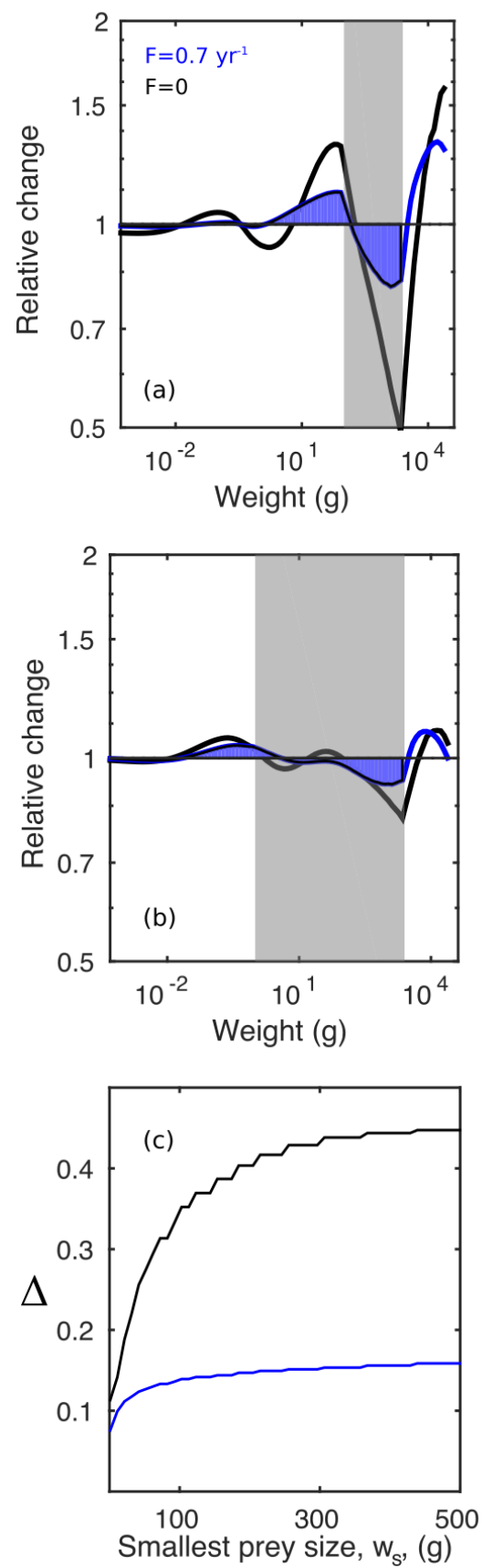

Smallest prey size, $\mathrm{w}_{\mathrm{s}},(\mathrm{g})$

Figure 3. Impact of tuna in the northern North Sea using the ratio $N_{01} / N_{00}$ (black) and $N_{11} / N_{10}$ (blue) to evaluate the effects of tuna consumption on an unexploited and exploited $\left(F=0.7\right.$ year $\left.^{-1}\right)$ ecosystem respectively. Tuna consumption $\left(\mathrm{S}_{\mathrm{T}}=150 \mathrm{kton}_{\mathrm{year}}{ }^{-1}\right)$ is applied in the prey size range $w_{S} \leq w_{P} \leq w_{L}$ (grey areas) with $w_{L}=2.5 \mathrm{Kg}$ and (a) $w_{S}=100 \mathrm{~g}(\mathbf{b}) w_{S}=1 \mathrm{~g}$. The index $\Delta$ Eq. 3 is graphically shown as the area under the relative change curve (blue shaded area). In (c) the value of $\Delta$ is shown at different values of $w_{S}$ for unexploited (black) and exploited (blue) ecosystem. 

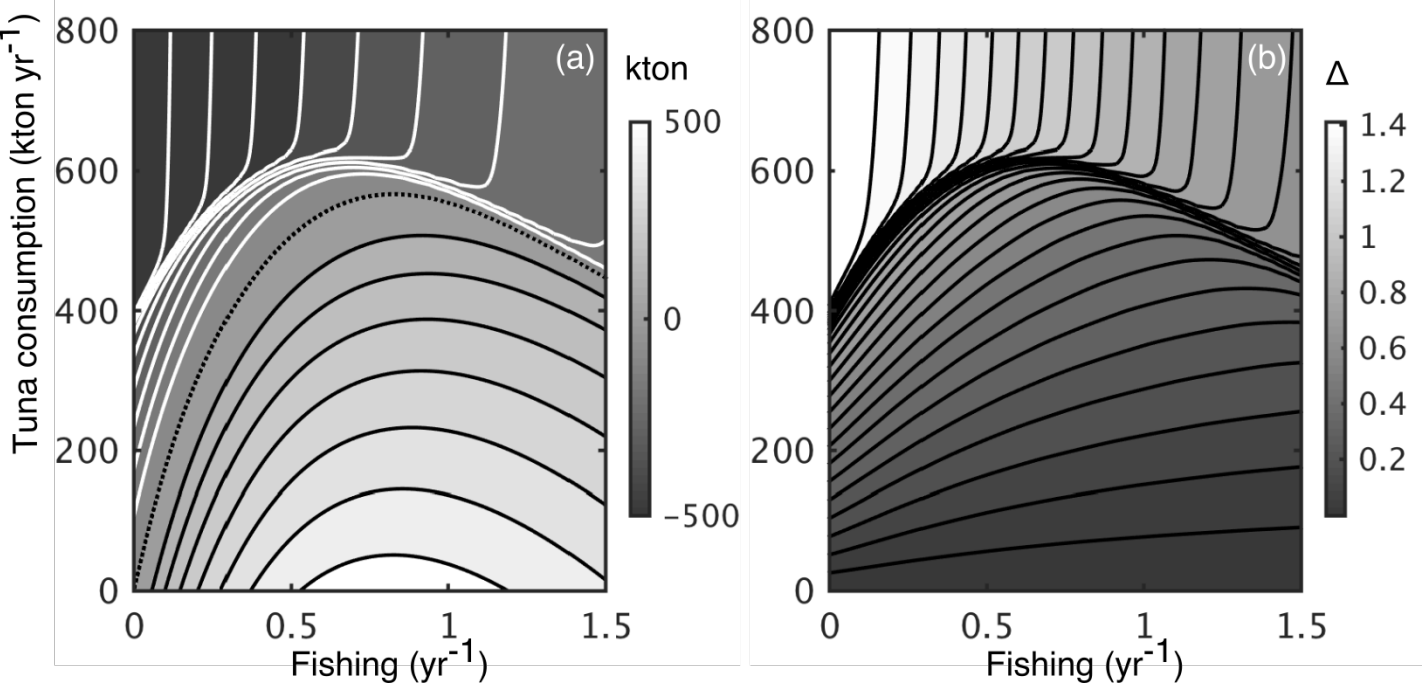

Figure 4. Direct impact of fishing (F) and consumption by tuna $\left(S_{T}\right)$ on (a) prey biomass (a) and (b) size-structure index $\Delta$ (Eq. 3). The tuna prey biomass is calculated as the difference between the equilibrium prey biomass, in a specific fishing and consumption scenario, and the unperturbed case, when $\mathrm{F}=0$ and $S_{T}=0$. White contour lines are for negative values, black solid lines for negative biomass values and the zero contour line is shown with a dashed line. The prey interval is $w_{S} \leq w_{P} \leq$ $w_{L}$, with $w_{S}=100$ gr and $w_{L}=2.5 \mathrm{~kg}$. The index $\Delta$ is defined in Eq. 3 as the changes in size structure for $w \leq w_{L}$. 


\section{Encounter and consumption}

Prey size selection

Volumetric search rate

Encountered food

Maximum consumption rate

Feeding level

\section{Growth and reproduction}

Maturation function

Somatic growth

Egg production

\section{Recruitment}

Population egg production

Recruitment

\section{Mortality}

Background mortality

Predation mortality

Fishing selectivity

Fishing mortality

\section{Resource spectrum}

Growth rate

$$
\frac{\partial N_{r}(w)}{\partial t}=r_{0} w^{n-1}\left(\kappa(w)-N_{r}(w)\right)-\mu_{p . r}(w) N_{r}(w)
$$

$$
\phi\left(\frac{w_{\text {prey }}}{w}\right)=\exp \left[-\left(\ln \left(\frac{\beta w_{\text {prey }}}{w}\right)\right)^{2} /\left(2 \sigma^{2}\right)\right]
$$

$$
V(w)=\gamma w^{q} ; \gamma=\frac{f_{0} h \beta^{n-q}}{\left(1-f_{0}\right) \sqrt{2 \pi} \kappa_{r} \sigma}
$$

$$
E(w)=V(w) \sum_{j} \int_{0}^{\infty} \phi\left(\frac{w_{\text {prey }}}{w}\right) N_{j}\left(w_{\text {prey }}\right) w_{\text {prey }} \mathrm{d} w_{\text {prey }}
$$

$$
f_{i}(w)=\frac{E_{i}(w)}{E_{i}(w)+I_{\text {max } i}} .
$$

$$
\begin{gathered}
\psi(w)=\left[1+\left(\frac{w}{w_{\text {mat. } . i}}\right)^{-10}\right]^{-1}\left(\frac{w}{W_{i}}\right)^{1-n} \\
g_{i}(w)=\left(\alpha f_{i}(w) I_{\text {max. } i}-k_{i} w^{p}\right)(1-\psi(w)) \\
g_{r}(w)=\left(\alpha f_{i}(w) I_{\text {max } . i}-k_{i} w^{p}\right) \psi(w)
\end{gathered}
$$

$$
R_{p . i}=\epsilon /\left(2 w_{0} N_{i}\left(w_{0}\right) g\left(w_{0}\right)\right) \int_{w_{0}}^{W_{i}} \psi(w) N_{i}(w) g_{r}(w) d w
$$

$$
R_{i}=R_{\max . i} \frac{R_{p . i}}{R_{\max . i}+R_{p . i}} \xi(t)
$$

$$
\mu_{\text {p.i }}\left(w_{\text {prey }}\right)=\sum_{j} \int_{w_{0}}^{\infty} \phi\left(\frac{w_{\text {prey }}}{w}\right)\left(1-f_{j}(w)\right) V_{j}(w) \theta_{i j} N_{j}(w) \mathrm{d} \text { M12 }
$$

$$
S_{i}(w)=1 /\left(1+e^{(S 1-S 2 w)}\right)
$$

$$
\bar{F}_{i}(w)=S_{i}(w) F_{i}
$$

